\title{
English for special purposes
}

\section{Rimazhon SOTLIKOVA ${ }^{1}$}

National University of Uzbekistan

\begin{tabular}{l} 
ARTICLE INFO \\
\hline Article history: \\
Received October 2021 \\
Received in revised form \\
15 October 2021 \\
Accepted 20 November 2021 \\
Available online \\
15 December 2021 \\
\\
\hline Keywords: \\
English for Special Purposes \\
(ESP), \\
professional competence, \\
learning objectives, \\
functions and roles of the \\
teacher, \\
motivation, \\
profession, \\
interest.
\end{tabular}

\begin{abstract}
This article examines the role of the English language in the world language space, its importance for global communication in the era of globalization. The issues of the emergence and development of the concept of "language for special purposes" are described. Various approaches to its definition are analyzed, the scope of the concept and its place in modern linguistics are clarified.
\end{abstract}

2181-1415/C 2021 in Science LLC.

DOI: https://doi.org/10.47689/2181-1415-vol2-iss11/S-pp116-125

This is an open access article under the Attribution 4.0 International (CC BY 4.0) license (https://creativecommons.org/licenses/by/4.0/deed.ru)

\section{Maxsus maqsadlar uchun ingliz tili}

\footnotetext{
Kalit so'zlar:

maxsus maqsadlar uchun

ingliz tili (ESP),

kasbiy kompetensiya,

o'quv maqsadlari,

o'qituvchining funksiyalari

va rollari, motivatsiya,

kasb,

qiziqish.
}

\begin{abstract}
ANNOTATSIYA
Maqolada ingliz tilining jahon lingvistik makonidagi o'rni, globallashuv davrida jahon aloqalari uchun ahamiyati ko'rib chiqildi. "Maxsus maqsadlardagi til" tushunchasining paydo bo'lishi va rivojlanishi masalalari bayon qilinib, unga ta'rif berishda turlicha yondashuvlar tahlil qilingan, tushunchaning qamrovi va zamonaviy tilshunoslikdagi o'rni ko'rsatilgan.
\end{abstract}

\footnotetext{
${ }^{1}$ Faculty of Foreign Philology, Department of Foreign Language and Literature, National University of Uzbekistan. Tashkent, Uzbekistan.
} 


\section{Английский язык для специальных целей}

Ключевые слова:
Английский для
специальных целей (ESP),
профессиональная
компетенция,
цели обучения,
функции и роли учителя,
мотивация,
профессия,
интерес.

\section{АННОТАЦИЯ}

В данной статье, рассматривается роль английского языка в мировом языковом пространстве, его значимость для всемирного общения в эпоху глобализации. Описаны вопросы возникновения и развития понятия «язык для специальных целей». Анализируются различные подходы к его определению, уточняется объем понятия и его место в современной лингвистике.

In the 21st century, the processes of globalization and integration have affected all spheres of human life and marked the beginning of a new era, when the need for professionally oriented communication becomes dominant [1]. The modern, constantly changing reality makes high demands on specialists who must not only have professional skills and abilities, but also be highly qualified specialists in the field of language communication. Language as the main means of communication serves as a kind of mirror reflecting the changes taking place in society.

Currently, English is a mixed language, it is assigned the role of a world language [2], therefore, English proficiency is the path to knowledge, education, technology and scientific progress, business and international trade.

Since there are several fields of activity, education, science, etc., he came to represent a type of language that could suit each area, so English for Professional Purposes (ESP) appeared, which refers to the teaching or learning of a language for a specific field. (for example, law, medicine or for business in general) [3].

The emergence of such a direction as ESP (English for specific purposes), i.e. English for special purposes, shows that the need for teaching a specialized language is constantly growing, as a result, new problems arise, actual goals and objectives are indicated, both for students. and for teachers.

The term ESP appeared in the language no more than 60 years ago after World War II, when fundamental changes took place in the global geopolitical situation. Language learning approaches and learning objectives have been changed to match new trends in economics, trade and politics.

Today, knowledge of a foreign language, and in particular English, is considered not only the basis for better communication, but also an important source of technological progress, since it allows you to quickly exchange information and explore common global problems. The development of language skills is aimed at actively expanding students' knowledge of the English language. In higher educational institutions, in the classroom, language courses, texts are always used for specific professional areas (architecture, business, civil engineering, electronics, ecology, management, etc.). Such texts of a professional orientation, as a rule, should be focused on the communication needs of students of a particular university. However, teaching English for professional purposes involves much more than teaching English through specific materials and content. Professional English teaching combines the development of linguistic skills and the acquisition of specific information. It is believed that even homework should be related to both the specialty and the skills mentioned. 
English for Specific Purposes includes:

- English for Academic Purposes (EAP) - English for

academic purposes so that students can read texts, attend lectures, take exams, etc.

- English for Professional Purposes (EPP) - English for

professional goals related to the specifics of the work of students. The composition of the EPP includes English for Business (EFB) - Business English and many other varieties of the English language. [5]

The main characteristics of the ESP are:

- a limited set of words and expressions, selected from the language as a whole,

since a limited set of words satisfies the requirement of representing fragments of a specialized picture of the world;

- ESP uses vocabulary lexical units that are not found in other areas, but the set of syntactic constructions is universal for a particular language in general;

- ESP is used for accurate, unambiguous transmission of information.

Thus, we can conclude that it belongs to a certain area of knowledge and its characteristics are:

- accuracy and unambiguity;

- neutrality;

- practical (applied) nature [6].

With regard to the syntactic characteristics of ESP, then for it

are characteristic:

- rather long sentences with a large number of subordinate clauses with both a compositional and a subordinate link, the use of introductory words and structures;

- passive voice of verbs;

- substantiation;

- a large number of definitions (attributes) [6].

ESP is taught in many universities around the world. Many professional associations of English teachers (TESOL, IATEFL) have ESP sections. Much attention is paid to the design of ESP courses. ESP training has a lot in common with English as a Foreign or Second Language and English for Academic Purposes (EAP). The booming business English can be seen as part of the broader concept of English for Specific Purposes.

ESP differs from standard English teaching in that the instructor must not only be proficient in Standard English, but also have technical experience. When international doctors learn English, they need to learn the names of their instruments, the conventions and techniques of their profession before they can perform the operation in an ethical manner. ESP for Medicine courses will be relevant to any medical profession, just as studying electrical engineering will be beneficial for a foreign engineer. Some ESP scholars recommend a "two-level" ESP course: the first, covering all general knowledge in a specific field of study, and then the second level, which will focus on the specificity of a person's specialization.

When learning English for special purposes, the results of trainees are most dependent on their motivation to learn. Motivation is a complex process influenced by various factors. The needs of the trainees are the most important. These needs are formed and met in a specific social environment. When a student notices favorable external conditions for satisfying a need, a motive appears, and he is ready to act to satisfy the need. The main motivational mechanism is the formation of meaning, that is, understanding the 
causal relationship between the performance of certain actions and the satisfaction of needs. Interesting is the orientation of the subject (learner) towards acquaintance with an object (material or ideal) capable of satisfying his need. It is the teacher's job to set learning goals and create an environment for achieving them that will motivate students to learn.

In order to ensure the effective acquisition of certain language knowledge and skills, it is necessary to encourage and enhance the student's interest. Students should be encouraged to actively participate in the learning process and improve their language skills. If they are highly motivated and strongly interested in actively participating in the learning process, then mastery of any subject will be extremely successful. Learner interest means commitment to the learning process. Lack of motivation leads to poor performance, frustration, and boredom. Interest is a multifaceted concept and consists of three main components: cognitive interest associated with the degree of student interest and investment in learning; behavioral interest associated with student behavior in social, academic and educational contexts, aimed at mastering the educational program; emotional interest related to reactions to the learning environment, including teachers, other learners, institutional climate, etc. There has been a lot of discussion in the scientific community lately that ESP courses should be taught by subject specialists, it is believed that they are more competent in certain areas, as opposed to general English teachers who have only linguistic competence. The latter are often unable to explain and actualize at the proper level the phenomena and processes inherent in the English language for special purposes.

What is the main task of that area of theory and practice, which can be attributed to language for special purposes?

Apparently, this is the identification of the general and specific in mastering a foreign language for different purposes. Everyone knows that linguistics deals with language, and the special goals of its study are already questions of lingual didactics and methodology, let's not forget about the theory of professional communication. After all, not only the language itself, but also the nature of communication is specific to a particular profession.

The problem of language for special purposes has no boundaries. It is interdisciplinary and affects functional stylistics, the theory of intercultural communication, features of various professional sublanguages, the ratio of general and specific in them, linguo didactic and methodological aspects of teaching languages to different categories of students, and much more.

General English teachers often have a very vague understanding of the material discussed or presented and, as a result, are unable to provide students with a quality educational product. Most ESP courses are based on authentic texts, real situations, experiences and experiments, where a large number of specialized terminology is used, a comparative analysis of various processes is carried out, complex technical, economic, legal aspects and theories are considered. A subject teacher is easily able to explain to students all the issues and phenomena that cause difficulties, besides, he has real professional experience in these areas.

However, along with these positive characteristics, the subject teacher usually does not know enough, and sometimes does not know the methodology of teaching a language, the principles of the language system, the peculiarities of grammatical and lexical structures. As a result, despite a high level of language proficiency and in-depth knowledge of the subject area, these teachers are also insufficiently prepared to deliver ESP courses. 
ESP students usually have a good idea of where they will be using English. Having decided for themselves what science to do, they see learning English as an addition to this. The teacher's ability to communicate and be a mediator creates the necessary atmosphere in the classroom. Students learn a language when they can use the language in interaction with other participants. This is why the teacher must create an atmosphere in the language lesson that would support the students. Students must be confident in themselves in order to communicate, and everything depends on the teacher's skill, on the degree of his responsibility for the formation of students' confidence.

The rapid development of modern society, scientific and technological progress and the growing needs of intercultural communication, including in special areas, clearly require further research in the field of ESP. One of the priority areas at present is the development of computational linguistics, within which there are ample opportunities for scientific research, including the corpus method.

\section{REFERENCES:}

1. Popova Z.D., Sternin I.A. Language and national picture of the world. Voronezh: Istoki, 2017. - P. 61.

2. Crystal D. English as a global language. Cambridge: Cambridge. University Press, 2003. - P. 212.

3. International Teacher Training Organization. EFL Teaching terminology and glossary. 2005. URL: http://www.teflcertificatecourses.com/tefl articles / efl teaching terminology. html.

4. Akhmanova O.S. Optimization of natural communication systems [Text] / O.S. Akhmanov. - M., 1973.

5. Scrivener J. Learning Teaching [Text] / J. Scrivener // Macmillan Books for Teachers, 2005. - P. 426.

6. Beier R. Englische Fachsprache [Text] / R. Beier. - Stuttgart, Kohlhammer, 1980. - P. 41. 